\title{
The International Stature of Geoscience: A Cause for Concern
}

For some, the appearance on the cover of Time Magazine on May 6,1985 , of a beleaguered dinosaur under sentence of death from cometary impacts, may have been the ultimate sign of public recognition of the work we do and the ideas that we generate in the geosciences. At least the photos and interviews in the accompanying article of the Alvarezes, Jack Sepkoski, David Raup and Walter Clemens, put geologists for a moment at the level of a North American "personality"! A more serious measure of the increasing interest in the geosciences can be found in the rather full coverage by Nature, Science, New Scientist, Scientific A merican and other generalist journals of new developments and ideas in plate tectonies, human paleontology, marine geology, and mass extinctions. On the international front of science and technology, however, the stature of the geological sciences as compared to that accorded to chemistry, physics or the life sciences may be questioned.

Take the United Nations University for example. Established in 1973, the UNU is an innovative institution working through research and advanced training to bring about a better understanding of world problems. It works through a network of scholars and associated institutions in over 60 countries, and among its major programs are "Energy Systems and Policy," "Resource Policy and Management" and "Science, Technology and the Information Society." UNU works with geographers (and the International Geographical Union) in some of these areas, but nowhere in its list of council members, coordinators, or specific projects are geoscientists visible.

The Third World Academy of Sciences is a more recent mechanism for bringing scientists together and accelerating both the advancement of sciences in Africa, Asia and Latin America and the application of science to problems in developing countries. The published membership of TWAS seems devoid of geologists as does the list of 234 scientists who attended its recent conference on international cooperation in science. Headed by Nobelist Abdus Salaam, TWAS works from a base at the International Centre for Theoretical Physics (ICTP), which itself has an outstanding track record in global scientific research and training, but no counterpart in geology.

Great recent advances in the agricultural sciences have been attributed in considerable measure to the existence of an international network of research centres like the International Rice Research Institute in the Philippines. Although few would seriously question the importance of research on food production or the great strides made in recent years in plant genetics, seed banks, or cropping techniques, the geological and mineralogical aspects of soils appear to be relatively neglected, especially from the aspect of appropriate fertilizers and soil conditioners. Likewise, it is no doubt proper that a new International Centre for Genetic Engineering and Biotechnology is now being established with initial bases in New Delhi and Trieste and a work program costing $\$ 40$ million for the first five years. UNIDO has taken the lead in setting up these Gen-Tech centres, as has Unesco in organizing and supporting the Chemistry for Development program and the International Biological Network.

In the earth sciences we do have IGCP, one of the brightest stars in the sky of Unesco (and IUGS), and, on a rather less multi-national basis, the new Ocean Drilling Program.
Although they are not research-oriented, there are also groups like CIFEG (the International Centre for Training and Exchanges in Geosciences) in Paris, which sponsors training courses and publications, and CPCEMR (Circum-Pacific Council for Energy and Mineral Resources), which organizes map projects and conferences on a regional scale.

The Lithosphere Program (ILP) is, however, hamstrung by lack of funding, as increasingly is one of the most successful regional cooperation organizations in geology, CCOP (the subject of a review in this issue by S.K. Chung and J.A.M. Ten Cate). A final example of an important international geological organization blocked by lack of support in its efforts to function is the World Organization of Volcano Observatories (see Souther et al. in Episodes, December 1984). WOVO could provide the framework for monitoring volcanoes worldwide, in the search for ways to reduce damage from eruptions. And of course there is the Association of Geoscientists for International Development, the first international NGO of individual scientists specifically concerned with the problems of developing countries. An appeal for support from AGID was published in the last issue of Episodes.

It is obviously not for lack of efforts by dedicated individuals that the geosciences seem rather lack-lustre on the international map of "big science." Perhaps what is needed is an organization with prestige to argue the case loudly, effectively and often for international recognition of and support for the earth sciences. There is surely none better placed than IUGS, or more free to act as an international advocate on behalf of the earth sciences. It should not be beyond the capacity of the Union to devise new ways to attract support for global science. Among the IUGS family, and especially its affiliated groups, are many articulate, experienced, imaginative and forceful voices, which if mobilized could help to ensure that the geosciences are properly represented in international scientific forums. It would be a great waste if successful ventures like CCOP, the UN's Regional Mineral Development Centres in Bandung and Dodoma, ILP and AGID were to falter, or WOVO to remain a premature baby. And the contributions of an international geoseience institute with the power of ICTP or the new Gen-Tech centres, focussing for example on the geology of the tropics, ground-water or on agricultural geology, could prove of tremendous importance both to science and development.

FORTHCOMING ARTICLES

PROTEROZOIC EVOLUTION in SW AFRICA

The SILURIAN at 150

The EUROPEAN FEDERATION of GEOLOGISTS

WORLD DATA BASE for PETROLOGY 